\title{
Waste Prevention Action Nets
}

\author{
Corvellec, Hervé; Czarniawska, Barbara
}

Document Version

Final published version

Publication date:

2013

\section{License \\ CC BY-NC-ND}

Citation for published version (APA):

Corvellec, H., \& Czarniawska, B. (2013). Waste Prevention Action Nets. Paper presented at Reduce, Reuse and Recycle, Borås, Sweden.

Link to publication in CBS Research Portal

\section{General rights}

Copyright and moral rights for the publications made accessible in the public portal are retained by the authors and/or other copyright owners and it is a condition of accessing publications that users recognise and abide by the legal requirements associated with these rights.

Take down policy

If you believe that this document breaches copyright please contact us (research.lib@cbs.dk) providing details, and we will remove access to the work immediately and investigate your claim. 


\title{
Waste prevention action nets
}

Hervé Corvellec*

Department of Service Management and Service Studies, Lund University

and Gothenburg Research Institute (GRI), University of Gothenburg

and

Barbara Czarniawska

Gothenburg Research Institute (GRI), University of Gothenburg

* Author for correspondence

Text presented at Reduce, reuse and recycle - environmental and social challenges,

Workshop at the University of Borås, Sweden 20th-22nd of November 2013

\begin{abstract}
Although waste prevention is considered the best possible waste management option in the European waste hierarchy model, it is unclear what constitutes waste prevention. To address this lack of clarity, this text presents an analysis of four Swedish case studies of waste prevention: a waste management company selling waste prevention services; the possibility offered to Swedish households to opt out of receiving unaddressed promotional material; a car-sharing program; and a re-use center. This analysis is informed by an action-net perspective that focuses on the way organizing emerges from connecting actions, often prior to networking between actors. In conclusion, we stress that waste prevention rests on the invention of new modes and patterns of interactions that both build and disrupt the existing institutional order and underscore the importance of physical artifacts and dedicated infrastructures for waste prevention initiatives.
\end{abstract}




\section{Introduction}

According to the European waste directive (European Commission 2008/98/EC), waste policy in the Member States of the European Union is to be organized according to the so-called waste hierarchy. This is a model that ranks waste management alternatives from best to worst, with waste prevention being the best possible option, followed by re-use, recycling, incineration with energy recovery, and land filling (Article 4.1). Several motives have been advanced to advocate the use of the waste hierarchy, among them, reducing the use of resources (Preamble 6), supporting the use of recyclates (Preamble 29), and reducing greenhouse gas emissions originating from waste disposal on landfills (Preamble 3). More generally, the purpose of the waste hierarchy is to prompt new forms of engagement with waste that reorganize material flows at the precommodity and postcommodity phases of products around the notions of resources and circularity (Hultman and Corvellec 2012).

The waste hierarchy is an imperative imposed on Member States in the name of environmental protection: "The waste hierarchy generally lays down a priority order of what constitutes the best overall environmental option in waste legislation and policy" (European Commission 2008/98/EC). Departure from the model is possible under certain conditions: "departing from such hierarchy may be necessary for specific waste streams when justified for reasons of, inter alia, technical feasibility, economic viability and environmental protection" (Preamble 31); in particular "departing from the hierarchy where this is justified by life-cycle thinking on the overall impacts of the generation and management of such waste" (Article 4.2). The waste hierarchy is "a priority order in waste prevention and management legislation and policy" (Article 4.1).

Sweden is one of the member states that has incorporated the hierarchy into its legislation (Environmental code, SFS 1998:808) and its national waste governance. Its national waste strategy describes the waste hierarchy as establishing the direction toward a more resource-efficient society: "The waste hierarchy shall apply as a prioritisation scheme for legislation and other instruments" (Naturvårdverket 2012). Being a hierarchy, the model does not simply list waste management options; it ranks them to set the political, legal, and practical course of national waste policies. 
Waste prevention is the highest step of the waste hierarchy - the best possible way to deal with waste. The waste directive defines waste prevention as:

measures taken before a substance, material or product has become waste, that reduce: (a) the quantity of waste, including through the re-use of products or the extension of the life span of products; (b) the adverse impacts of the generated waste on the environment and human health; or (c) the content of harmful substances in materials and products (European Commission 2008/98/EC).

A merit of this definition is its focus on the two major aspects of scoping waste prevention: prevention of waste generation (quantitative prevention) and prevention of harm through waste (harm prevention) (Arcadis Belgium 2010). Another merit is the definition, which is broad enough to allow a wide range of activities to be labeled as waste prevention.

Waste prevention initiatives can take many forms: awareness and education activities, ecodesign, extended producer responsibility, green public procurement, labeling and certification, marketing, positive and negative financial stimuli, prevention targets, product standards, re-use, technology standards, or voluntary agreements. Furthermore, waste prevention can refer to any of the lifecycle phases of a product or service: design, extraction, production, distribution, use, waste and end-of-waste (Arcadis Belgium 2010). The best waste prevention initiatives singled out by the European Pre-Waste research project are as different as the optimizing of packaging for organic food products, the re-use of furniture, the promotion of decentralized composting, an ecotaxation on disposable plastic bags, food weighing in schools, the introduction of washable nappies in the nursery, the development of water dispensers, and municipal information to the public (Pre Waste 2010).

This plethora of examples notwithstanding, waste prevention is neither obvious nor uncontroversial. As critics such as Davis (2009) have observed, waste prevention plans tend to express ambitions rather than leading to actual results. The implementation of waste prevention plans often ends up on the bottom of the priority ranking of resource allocation (UNEP 2011). Waste prevention runs into established waste management 
infrastructures, which may function as lock-ins, especially if existing infrastructures are deemed to deliver satisfying solutions (Corvellec, Zapata Campos et al. 2013). And, like many other attempts to change consumption patterns, it encounters socio-cultural difficulties, (Bekin, Carrigan et al. 2007). The fact is that waste prevention measures tend to aim at slowing or reducing material flows in society. As such, they have the potential to attract the ire of many kinds of advocates of growth. The European Furniture Industries Confederation (EFIC), for example, has recently criticized the passing of a French regulation about furniture recycling:

The European furniture industry is genuinely surprised that while all the European efforts are concentrated in the completion of the Single Market, in order to boost growth and provide jobs to emerge strongly from the crisis, Member States implement national regulation that hinder the same idea of Single Market, hamper free movement and impede competition. (Wiesner 2013) For this industry representative, the French recycling scheme is no less than a repudiation of freedom of enterprising, competitiveness, growth, and employment.

The implementation of waste prevention plans and measures is often slowed down, or even prevented, by an unclear division of tasks and responsibilities. Whereas the responsibility for waste management is usually clearly shared by public or private waste producers and waste management companies, it remains unclear where the practical responsibility for waste prevention lies. Who is to imagine, incentivize, finance, develop, support, and evaluate waste prevention schemes? Producers, including designers? Distributors? Planners? Waste producers, either corporations or households? Waste management companies? All of the above? As of today, these questions have no answers.

Despite the definitional efforts of European Union authorities, the contours of waste prevention remain blurred. Composting constitutes prevention in some countries but not in others. Re-use is considered waste prevention because it is performed on nonwaste; preparing for re-use is not considered prevention, however, as it is performed on waste. Yet it is often next to impossible to distinguish between the two (Arcadis Belgium 2010). It is not possible to define waste prevention once and for all and everywhere. And that is probably just as well, considering the waste preventing innovations yet to come. 
The highest step of the waste hierarchy may involve a radical rupture with conventional ways of imagining the relationships between nature and economy (Hultman and Corvellec 2012). The crux of the problem is that prevention differs in character from management. Whether it is a matter of preventing increases in energy use, urban transportation, or greenhouse gases, the rationale of prevention is to avoid something coming into being. It is a very different rationale from management: taking care of something that already exists.

We approach waste prevention initiatives as "the connection, re-connection, and disconnection of various collective actions to each other, either according to patterns dictated by a given institutional order or in an innovative way" (Czarniawska 2010). Our contention is that waste prevention requires and encourages the construction of new actions nets, and/or the reconstruction of existing ones. By action nets we mean assemblages of collective actions, connected to one another because they are perceived, within a given institutional order, as requiring each other (Czarniawska 2004); or, if new, because they are perceived as effective means of accomplishing a goal that lies outside the present order. A charity re-use center is based on the assumption that some people are ready to give things away, whereas others are ready to acquire and use second-hand stuff. A car-sharing program is organized by people catering to those who want to rent a car by the hour - people who design their car usage according to the specificities of the scheme. To examine action nets is to unfold the connecting of actions. Eventually, the connections between these actions get stabilized. Then and only then it is possible to speak of actors as being in an actor-network (Latour 2005).

To prevent waste from being created in the first place requires the invention, development, and stabilization of new patterns of interactions. Translating the ambitions expressed in the highest step of the European waste hierarchy requires the invention, development, connection, and stabilization of nets of actions based on new and often innovative understanding, priorities, habits, artifacts, to mention a few things. We speak here of moving beyond the ABC (attitude, behavior, and choice) model of social changes toward sustainability that dominates the present understanding of social change for environmental transitions and sustainability (Shove 2010). Creating new action nets is not merely presenting consumers with new options with the hope that 
they will be induced into making choices toward some kind of increased sustainability. It is a matter of letting new social habits, conventions, and practices become a new normality. The use of fossil-fuel-based single-use plastic bottles is not natural, spontaneous, or universal. Rather, it is a relatively new mobile way of containing water (Hawkins 2011) that requires long nets of extraction, production, and distribution. Picking up a plastic bottle of water to throw it away a few minutes later cannot be reduced to an individual utility-maximizing choice. It is an action embedded in a specific set of other collective actions - a mobile mode of consumption, for example - as is the idea of preventing waste by not using a fossil-fuel-based single-use plastic bottle. An action-net perspective on waste prevention clarifies the fact that waste prevention is a matter of developing new connections among collective actions that will hopefully result in less, if any, waste and adverse impact on the environment, as per the European Union's definition of waste. It also underscores the need to understand transition policies as the creation of new infrastructures that make possible but also constrain the emergence of new action nets.

\section{Part 1: An action-net perspective}

The concept of action nets (Czarniawska 2004) originates in a combination of new institutional theory (Powell and DiMaggio 1991) and actor-network theory (ANT) (Latour 2005). From new institutional theory, it borrows the insight that it is possible in each time and place to speak of a prevailing institutional order in the sense of an arrangement of institutions that dictates which actions, conventionally, should be tied together. In the current institutional order, for example, those who produce are supposed to try to sell their products and those with money are supposed to save or invest it. From actor-network theory, the concept of action nets borrows the idea that organizing is a matter of building relationships among people, things, words, and concepts though actions. Waste collection in residential areas presupposes that residents take their containers to the curbside, and that waste collection companies provide adequate vehicles and follow announced collection routes and schedules.

From an action-net perspective, the analysis begins earlier than actor-network theory would suggest: before those who do something become "actors", and before they build 
networks. From a network perspective, actors come first, networks come second, and actions in a network come third. But from the action-net perspective, actors are no less given nor pre-existing than the rest of what Latour (2005) calls the social: actions come first; actors come second; and networks, if they exist at all, come third. The temporality of an action-net perspective is thus the opposite of the temporality assumed from a conventional network perspective.

Rather than speaking of an actor, therefore, researchers taking an action-net perspective speak of an "actant" - that which accomplishes or undertakes an act (Greimas and Courtés 1982). Actants can be individual humans or collectives; they can be artifacts created by humans, such as a machine or a protocol; but they can also be natural things such as a molecule or animals. This choice of words emphasizes a shift in attention from being (an actor) to doing (an actant). It caters to the fact that not all actors are constituted as such at all points in the organizing process. It is through the actions they perform successfully that actants become actors; otherwise they will remain objects of someone else's actions. It is also from their actions that actors derive an identity. People are not waste service providers, for example, before and unless they perform the type of activities that are associated with providing a waste service. What matters is the proven ability to act that way.

The function of the term "net" is to provide a signal that the focus is on the way actions rather than actors are connected. Of course this focus does not deny the existence of networks of actors - there are a great many of those, from private cliques to large corporations. The point of an action-net perspective is to capture organizing at an earlier stage, when things still need to be done, long before powerful actor-networks present themselves to an admiring audience. Actions in action nets are like threads that are woven or knotted together. If successfully stabilized, they will hold in ways that resist tractions and pressure to forces of deformation and displacement.

The action-net perspective is a processual approach to organizing (see, e.g., Hernes 2008), designed in contradistinction to essentializing approaches to organizations. Action-net perspective focuses on "what is being done, and how this is connected to other things that are being done in the same context" (Czarniawska, 2004:784). The 
purpose is to track the sequence of organizing, both within organizations and across organizational borders.

The nature of connections between actions is as varied as human imagination, but it always consists of translating the conditions of one collective action into those of another. It can be a matter of mutual adjustment. Recycling centers may hold extended open hours during the Easter weekend, for instance, to accommodate the fact that many individual home owners use this weekend to clean their gardens for spring. Or the connection can rest on introducing a new artifact, as when waste management companies ask households to sort food waste in special paper bags, or when refill fountains are installed in shops so people can fill their own containers when buying detergent. Likewise, connections can be established by individual human action, as when charities collect second-hand items from door to door; or they can be mediated by long chains of actants, human or non-human. In order not to dissolve back into nothingness, connections need to be maintained and, in the case of innovative action nets, perhaps even defended against the institutionalized options.

The notion of action nets owes a great deal to Karl Weick's definition of "organizing" as assembling "ongoing interdependent actions into sensible sequences, i.e. generate sensible outcomes" (Weick 1979). Weick's choice of words may suggest chains only, but he meant it as a temporal rather than a spatial sequence. Connecting actions require that actants make sense (Weick 1995; Weick 2011) of each other's actions, through translations (e.g., Callon 1986; Latour 2005), for example, that reformulate the Other's intention in ways that are intelligible and telling to oneself. Translation is "the mechanism whereby connecting is achieved" (Lindberg and Czarniawska 2006), or expressed differently, the process whereby actions are connected to each other.

How is an action net constructed? By envisioning the net backwards from the desired outcome, most likely - in this case, by preventing waste. Perhaps the exact cognitive processes are not especially important; such envisioning can be a matter of careful planning or design, or it can result from someone thinking that something needs to be done. But envisionings can also emerge serendipitously and develop as the actions unfold. 
The next step is connecting actions, by the means of translation (Lindberg and Czarniawska, 2006: 295), where translation, in the spirit of actor-network theory, is understood mainly non-linguistically, in the sense of transforming one action into another at the connection point. Clearly, a great deal of linguistic translation is also involved: from one kind of specialist vocabulary to another and from one language to another.

Once the connections between actions have been made, and the entire action net is in place, this connection must be stabilized and maintained in good shape. When relationships among actions are not only stabilized, but also a normative and cognitive fixity (that is, they can be justified in an appropriate vocabulary and taken for granted), they will become a basis for actors to acquire character ("he is a pioneer of waste prevention") and allow them to build networks ("no need to change those providers; we can rely on them").

Not all connections between actions will become stable, however, and a researcher's interest in an action net lies in showing whether or not and how ongoing processes of organizing practices build stable relationships (Lindberg and Walter 2013). Another interesting aspect of the construction of new action nets is the extent to which such innovative nets draw upon, adapt to, or change the existing institutional order.

\section{Part 2: Four cases of waste prevention}

In what follows, the action-net perspective has been used to analyze four Swedish cases of waste prevention, in order to map the social dynamics of such initiatives. The first example is the only case of corporate waste discussed here; it focuses on the production stage - the case of a waste management company selling waste prevention services to its waste producing customers (NSR, Helsingborg). The second case is one of three examples of household waste. It demonstrates the pre-consumption phase: an attempt at waste prevention, providing the opportunity to opt out of unaddressed promotional material ("No advertising, thank you" signs) offered to Swedish households. The third case is a car-sharing program (Sunfleet, Sweden) that illustrates the construction of an 
alternative pattern of consumption. The fourth case of waste prevention provides an example of the post-consumption phase: the construction of a re-use center (Kretsloppsparken Alelyckan) in Gothenburg. Together, these four cases of waste prevention initiatives provide insights into waste prevention initiatives at different stages of the product or service lifecycles.

\section{Case 1: Waste reduction services}

NSR is a solid waste management company co-owned by six municipalities in the region of Northwest Scania in Southern Sweden, and as such it is responsible for waste collection and waste treatment services in the entire region. NSR is an advanced waste management company; one of the major biogas producers in Sweden; a producer of biofertilizers; and, more generally, a company with unique competence in biological treatment, waste characterization, recycling, and landfill research (NSR 2013).

Since 2007, NSR has offered tailored waste reduction and waste prevention services to waste producing companies. This offer required the construction of a waste prevention services action net. Larger companies or companies with environmental ambitions are offered "a comprehensive waste management contract, with personal contact, proximity to services, and an overview of the waste management situation" (our translation, NSR 2011). Smaller companies are offered "effective management of waste streams, with custom waste collection and proximity to efficient service" (our translation, NSR 2011). Moreover, NSR provides hazardous waste consulting services to businesses throughout the region, "offering the services of its chemists and safety advisers in the classification and handling of all categories of hazardous waste, with the exception of radioactive waste" (NSR 2007).

Several action nets had to be initiated, coordinated, and articulated to give life to these services. NSR had to canvass waste producers within its geographical zone of activities; to proceed to systematic and standardized waste analyses in order to assess the kind and quantity of waste delivered today by waste producers with an interest in these service; to design custom-made waste management solutions for the materials in this waste, identifying how to process and where to sell them; to collaborate with the waste producer to redesign its internal material management processes to reorient material 
flows from waste to recycling; and to introduce economic incentives for waste producers to enter a waste reduction program, while maintaining its own profitability. In order to connect their actions to those of NSR, waste producers must integrate NSR's view into their material processes designs. They need to redesign their work processes to replace nonrecyclable material with material that NSR can recycle; install dedicated waste and material containers to sort their key waste streams by volume, worth, and toxicity; and to introduce incentive schemes to promote and monitor the internal waste prevention policy, by sharing with employees the savings gained through this policy, for example. Many of these actions have been undertaken in common by representatives of each company; but many other actions have been taken by NSR and waste producers with their own suppliers and customers.

NSR and vegetable wholesalers have developed a separate collection and processing system for unsold vegetables. Instead of being mixed with other waste, unsold vegetables are pressed; the water they contain goes with wastewater, nutrients are collected in a pure enough form to be directly fed into NSR's biogas production chain, and only the packages become waste. This press reduces costs for wholesalers by reorienting their waste toward the waste water management system, and increases their income by connecting the remaining material to energy production; the new action nets are acting on both ends of the economic value creation process.

In the case of a local thermal insulation manufacturer, NSR analysis led to ways of reprocessing bi-products to turn them into a filling material product that can be sold, rather than ending up as an inert material in an expensive landfill. It is noteworthy that this waste prevention action net contributed decisively to a decision to maintain the this plant when the international head office decided to terminate one of three similar plants in other European locations. Establishing a new action net prevented an actor from being reduced to a simple actant.

A press for unsold vegetables and a machine to upgrade waste into filling material both are visible traces, and stabilizers, of the connections that have been built to establish waste prevention services. But no less important are the less visible connections, such as common definitions of waste and materials; agreements on 
collection frequencies; and, more generally, a shared view of the relevance of thinking in terms of waste prevention.

\section{Case 2: "No advertising, thank you" signs}

The second case involves an action net that grafts itself onto an existing action net to reduce the latter. In 1993, the Swedish Royal Postal Agency (today Posten AB), the Swedish Consumer Agency, and the Association of Swedish Companies (SWEDMA), agreed to work together to address the issue of direct marketing. This agreement provided Swedish households with the opportunity to opt out of unaddressed promotional material from door-to-door mail distributors by simply placing a "No advertising, thank you" sign beside their mailbox or letter slot. Because the original sign did not stop civic information such as bus timetables, information from political parties, or free newspapers from being distributed, households were given the opportunity to post a "No free newspaper" sign by their mail slot. They can also turn down addressed advertising by listing themselves at a central register. Likewise, private individuals can register centrally to indicate that they do not want direct marketers to telephone them. (For the record, it is forbidden in Sweden to send unsolicited faxes, e-mails or SMSs (Konsumentverket 2013; Svensk Direktreklam n.a.)).

For householders to be able to stop unaddressed advertisements requires scores of actions to be coordinated into an action net. The efficacy of the "No ads" or "No free newspaper" signs depends on SWEDMA reminding its member organizations of the necessity to respect these signs, and the Swedish Consumer Agency's handling of complaints about failure to respect them. Likewise, registers for people to record their wish not to be disturbed by unsolicited phone calls must be connected to the databases that Swedish telemarketers use, and households need to monitor the calls by kindly reminding telemarketers that they are actually not allowed to do it. A continual connecting and reconnecting of these actions is necessary for the scheme to achieve its goals.

One noteworthy aspect of the No-ads scheme is the argument of some commercial actors: Opting out may cause people to miss crucial information - when a car is due for its mandatory annual checkup, for example (TV4 2013). Clearly, the No-ads action net 
runs against interests that find their expression in direct marketing action nets. The purpose of the No-ads action net develops in contradistinction to these nets and, more generally, conventional commercial action nets, in order to limit (some people would say "damage") their reach. The two are in competition in their attempts to impact consumers' behavior.

\section{Case 3: A car-sharing program}

A product of yet another waste reduction action net is Sunfleet, a business-to-consumer car-sharing service. The company was started in the early 1990s by Hertz and Volvo, as a way filling the market segment between permanent car ownership and occasional car rental. The service was developed around the notions of convenience, flexibility, cost effectiveness, and sustainability. Cost effectiveness refers to an absence of fixed costs and the opportunity for individuals to monitor their car transportation costs.

Sustainability in this case refers to the possibility of choosing the size of car that exactly fits the needs of the moment, to the incentive to choose other means of transportation such as cycling or public transportation whenever possible, and to Sunfleet's choice of fuel-efficient vehicles, often less than two years old. To clarify the contribution of car sharing to sustainability, the company quotes the Swedish Transport Administration's claim that one car in a sharing program replaces five individually owned cars. The company's commercial motto is "A car only when you want it". Sunfleet presents itself as a "car revolutionary", claiming to lead, together with its members, the way toward a more sustainable mobile society. It declares that its goal is to introduce car sharing in Sweden - to change how Swedes look at owning and using a car (Sunfleet 2013).

To develop a car-sharing action net, Sunfleet has had to develop new connections among the actions of car producers, financing bodies, and car-maintenance companies, but also with the municipality and other land owners that provide parking lots, and, of course, with people interesting in trying this kind of service. More specifically, members need to connect to the web-based booking system, learn the sharing scheme procedures, and adopt their patterns of automobile mobility to the specificities of the scheme, (the number of vehicles and which vehicles are available at what price, for example). In addition, Sunfleet has established collaborations with housing companies and organizations such as the City of Gothenburg and Gothenburg University to offer 
packaged solutions for carless urban dwellers. Parts of these solutions are hyperlinks that direct Sunfleet members toward environmental education programs, supporting a ride-sharing community, and hiring electric bicycles - all literal expressions of the connective logic of action nets.

The car-sharing action net rests on well-functioning economic, legal, technical, and behavioral connections between the actions described here. And these connections need to be maintained and redesigned whenever any of the actants and actors change their ways of doing things - that is to say virtually all the time. Ruptures in connection, such as poorly maintained vehicles or an ill-functioning booking system, would dissolve the action net and effectively stop the service.

\section{Case 4: A re-use park}

A fourth example of the materialization of a waste prevention action net is the Alelyckan re-use park. Alelyckan is an eco-cycle park started in 2007, owned and operated by the Municipality of Gothenburg in collaboration with charity organizations: a re-use station for construction material; the City Mission second-hand store; the Return House, with a workshop for reparations; an Eco Café and Eco Store; and a collection station. The Park offers the opportunity to donate reusable material before recycling and to buy donated, and sometimes repaired, goods in the park's thrift shops. Alelyckan is featured as a practical effort to climb up the waste hierarchy by contributing to a circular economy, a sensible opportunity for residents to save on resources and provide a better environment for everyone (Göteborg Stad n.a.). The environmental objective is to promote re-use and thereby reduce the volume of material delivered to waste processing; another goal is to increase the re-cycling rate for material that is often delivered as waste. A research study by the Swedish Environmental Research Institute using life cycle analysis (LCA) methodology has estimated that the park prevents 360 tonnes of waste per year, which indicates a potential for re-use parks to reduce the amount of bulky waste delivered to the Swedish recycling centers by over $5 \%$ (Ljunggren Söderman, Palm et al. 2011). Because charity organizations provide employment for people who may have difficulty finding conventional employment, Alelyckan also offers a social sustainability dimension(Avfall Sverige [Sweden Waste Management] 2011; Gyllensting 2011; Göteborg Stad n.a.). 
Alelyckan differs from conventional recycling centers in that visitors are asked by the staff upon arrival at a roofed hangar if they have something to donate to second-hand sales. Donated products in good condition are transferred to the thrift shops, where they are sold, possibly after repair, as used goods; the rest is sorted into different waste categories - materials recycling or energy recovery - and processed by Gothenburg's waste management company. This action net branches out into buying actions: the visitors to the park, having made their donations, have the opportunity of visiting shops that sell used building material, furniture, bicycles, clothing, and electronic goods The Alelyckan re-use park is thus not only a place where people can dispose of used stuff. It is also a place where people can acquire used goods for new uses. This combination of a recycling station and a re-use park lead (Zapata Campos and Zapata 2013) to claim that “At Alelyckan, materials and items 'unbecome' waste".

Alelyckan hosts several action nets. Building up the Alelyckan re-use park required the City of Gothenburg to finance the investment and provide the construction permit. It was also necessary for the Regional County Board to provide the environmental permit, and construction companies realized the construction plans. Charity organizations had to be persuaded to join the program, hire themselves in the facility and learn how to clean, sort, possibly repair, display, and sell whatever the visitors entrust to them. It also requires them to ask visitors systematically if they would be interested in giving away what they otherwise intended to dispose of. Furthermore, waste producing visitors have to prepare themselves to give away things. To reduce the negative impact of noted operational problems: that many people are unaware that they can give away useful goods and that visitors must learn to pack their items to accommodate Alelyckan's way of working with waste (Gyllensting 2011). They must also allow themselves be convinced of the relevance of re-use and the values of sharing, and to be open to consumption habits that include second-hand clothing or furniture. Timetables, waste definitions, marketing strategies, and a social and environmental pathos need to be connected if the Alelyckan re-use action net is to exist.

\section{Part 3: Action nets for waste prevention}

Several insights can be gained from analyzing these four waste prevention initiatives 
from an action-net perspective. It is possible to speak of waste prevention initiatives because the connections between the actions in the nets have reached, at least temporally, some level of stability. A sign of this stability is that the nets are no longer fully dependent on the idiosyncrasies of actants. The interactions are stable enough that a waste producer, a car manufacturer, or a charity organization can replace one another. They become stabilized to the point at which they can be seen as a pattern to be imitated. The Alelyckan re-use park has already migrated to a new administration in the City of Gothenburg and featured as a best practice in the EU Pre-Waster project (Gyllensting 2011). It now represents a model that other cities in Sweden and abroad can replicate or adapt to their need. Likewise, the No-ads scheme has served as a source of inspiration to establish a scheme that makes it possible to say "no" to unsolicited advertisement in mobile phones ads.

These nets are constantly evolving. Entrepreneurial actants and actor-networks are always connecting new actions into existing ones, or even action nets to one another. Some companies have even started selling ready-to-use "No ads" signs, for example. Likewise, texts like this one can connect these initiatives to new actions if they are considered as a source of inspiration by waste decision makers. Stability does not mean that actions within the net remain the same.

A second noteworthy aspect of these four waste prevention initiatives is that they give shape to specific envisionings of waste prevention: reducing the volume of unaddressed advertisements being produced and distributed; reorienting people from ownership to rental and use (which is a key tenet of what is called économie de la fonctionnalité in French (Bourg and Buclet 2005) ${ }^{1}$ ); promoting the idea of re-use as an alternative to disposal; and integrating the constraints and possibilities of contemporary waste management in the design of material management processes. Each initiative is an effort to reduce the volume of material throughput (Daly and Farley 2004) in the economy. Furthermore, it decouples waste production from economic growth, which is one of the key ambitions of a globally sustainable waste management (UNEP 2011). These envisionings may have existed before the first actions were taken; they may have

\footnotetext{
${ }^{1}$ Literally the economy of functionality, but unfortunately translated as service economy.
} 
emerged slowly along with the organizing process; or they may be born only after when people made retrospectively sense of what they have done. The point is that the action nets that have been built have given form to the intentions, desired outcomes, or planned results that prompted the first actions. Action nets materialize visions, but not as static structures, but as dynamic processes.

A third insight concerns the key role played by places and artifacts in action nets. Human actants appear to depend on good relationships with their non-human counterparts to connect waste reducing actions. All four initiatives in this study depended on dedicated technological devices: special waste containers, signs, roofed facilities, or booking systems. Action nets must also connect well to places, like householders' letter slots for the "No ads" scheme or the Helsingborg region for NSR's waste prevention services. Artifacts, quasi-objects, and places are central to constructing and maintaining connections. $^{2}$

Finally, action nets are always being constructed in relation - positive or negative - to existing action nets. The No-ads initiative is an effort to limit the spread of direct marketing action net. Sunfleet's car-sharing service creates an alternative to car ownership and car rental nets. NSR's waste prevention services challenge existing waste handling action nets. And the promotion of re-use at Alelyckan re-use park is a direct criticism of the familiar one-use consumption net.

Action nets are constrained by the existing institutional order, but they challenge this order as well. Indeed, the initiatives discussed here confirm that a new waste institutional order may be under development. In this new institutional order, "wasting less" could have become the leading societal narrative on waste (Corvellec and Hultman 2012), waste prevention could have become the element of the business model of waste management companies (Corvellec and Bramryd 2012), former lock-ins could have been transcended (Corvellec, Zapata Campos et al. 2013), circularity could have re-defined

\footnotetext{
${ }^{2}$ Incidentally, the dependence of waste prevention on dedicated infrastructures points to a paradox of waste prevention: The diminution of material throughput requires material installations that themselves contribute to a high level of throughput. And infrastructures dedicated to waste prevention are themselves doomed to become themselves waste one day. It may be relevant, therefore, to imagine initiatives aimed at preventing the waste related to waste preventing initiatives, and so on, and so on.
} 
the relationships of nature and the economy (Hultman and Corvellec 2012), and waste prevention could be considered as a necessary part of sustainable urban development (Zapata Campos and Hall 2013; Zapata Campos and Zapata 2013).

Action nets should not be viewed in isolation. They are nets that are parts of nets; they are embedded in other action nets. Car-sharing services are part of the wide net of car production, use, and maintenance; waste prevention services are part of larger nets, allowing recycling materials to re-integrate production processes in particular, and the economy in general.

The analysis of waste prevention made from the perspective of action nets demonstrates that, in practice, the diversity of waste prevention initiatives is doubled by a diversity of actions specific to each initiative. The richness and intricacy of waste prevention that is thus revealed strongly contrasts with the simplicity of the waste hierarchy model. We believe that developing waste prevention would benefit from a recognition of the farreaching diversity of waste prevention actions, a critical recognition, not least for construction of waste governance models for waste prevention.

\section{Acknowledgments}

We are grateful to María José Zapata-Campos and Patrik Zapata, who have shared their field material with us and commented on previous versions of this text. We are also grateful to Nina Colwill for her editorial help. Hervé Corvellec also acknowledges the kind hospitality of the Department for Organization at the Copenhagen Business School (Denmark), where he wrote his portion of the text. This study is part of the research project, From waste management to waste prevention - Closing implementation gaps through sustainable action-nets, financed by the Swedish Research Council FORMAS (Environment, Agricultural Sciences and Spatial Planning).

\section{References}

Arcadis Belgium (2010). Final report: Analysis of the evolution of waste reduction and the scope of waste prevention, European Commission DG Environment. Antwerpen, Arcadis. 
Avfall Sverige [Sweden Waste Management] (2011). Good Examples of Waste Prevention in Municipalities: A compilation of ideas for more sustainable production and consumption. Malmö, Avfall Sverige.

Bekin, C., M. Carrigan, et al. (2007). "Beyond recycling: 'commons-friendly' waste reduction at new consumption communities." Journal of Consumer Behaviour 6(5): 271-286.

Bourg, D. and N. Buclet (2005). "L'économie de fonctionnalité: Changer la consommation dans le sens du développement durable." Futuribles(313): 27-38.

Callon, M. (1986). "Some elements of a sociology of translation: domestication of the scallops and the fishermen of St Brieuc Bay." Sociological Review Monograph 32: 196-233.

Corvellec, H. and T. Bramryd (2012). "The multiple market-exposure of waste management companies: a case study of two Swedish municipally owned companies." Waste Management 32(9): 1722-1727.

Corvellec, H. and J. Hultman (2012). "From 'Less Landfilling' to 'Wasting Less': societal narratives, socio-materiality and organizations." Journal of Organizational Change Management 25(2): 297-314.

Corvellec, H., M. J. Zapata Campos, et al. (2013). "Infrastructures, lock-in, and sustainable urban development: the case of waste incineration in a Swedish metropolitan area." Journal of Cleaner Production 50(1): 32-39.

Czarniawska, B. (2004). "On Time, Space, and Action Nets." Organization 11(6): 773-791.

Czarniawska, B. (2010). Going back to go forward: On studying organizing in action nets. Process, sensemaking, and organizing. T. Hernes and S. Maitlis. Oxford, Oxford University Press: 140160.

Daly, H. E. and J. C. Farley (2004). Ecological economics: principles and applications. Washington (DC), Island Press.

Davies, A., R. (2009). "Clean and green? A governance analysis of waste management in New Zealand." Journal of Environmental Planning and Management 52(2): 157-176.

European Commission (2008/98/EC). Directive 2008/98/EC of the European Parliament and the Council on waste and repealing certain documents. Official Journal of the European Union $L$ 312/3. Brussels, European Commission.

Greimas, A. J. and J. Courtés (1982). Semiotics and language: an analytical dictionary. Bloomington, Indiana U.P.

Gyllensting, K. (2011). "Alelyckan Recycling Park, Sweden (Good Practice in Waste Prevention, International Pre-waste workshop: Sharing ways to tackle municipal waste prevention in cities \& regions, 28 March 2011, Brussels) " Retrieved October 28, 2013, from http://www.bruxellesenvironnement.be/uploadedFiles/Contenu_du_site/Professionnels/For 
mations_et_s\%C3\%A9minaires/Conf\%C3\%A9rence_Pre-waste_2011_(actes)/p2-postersgood-practices.pdf.

Göteborg Stad. (n.a.). "Kretsloppsparken Alelyckan [Alelyckan Re-use Park]." Retrieved October 28, 2013, from http://goteborg.se/wps/portal/invanare/miljo/avfall-och-atervinning/harlamnar-du-ditt-avfall/kretsloppsparkenaterbruket/!ut/p/b1/04_SjzQyMzG2NDQyNNWPOI_KSyzLTE8syczPS8wB8aPM4gMMvQItnAw dDfzdLd0MPEO8A9z8vH38Q83MgQoigQoMcABHA0L6_Tzyc1P1c6NyLAASBy_i/dl4/d5/L2dBIS EvZOFBIS9nQSEh/.

Hawkins, G. (2011). "Packaging water: plastic bottles as market and public devices." Economy and Society 40(4): 534-552.

Hernes, T. (2008). Understanding organization as process: theory for a tangled world. Oxon, Routledge.

Hultman, J. and H. Corvellec (2012). "The European Waste Hierarchy: from the sociomateriality of waste to a politics of consumption." Environment \& Planning A 44(10): 2413 - 2427.

Konsumentverket. (2013). "Nej till reklam." Retrieved October 29, 2013, from www.konsumentverket.se/Lagar--regler/marknadsforing-och-reklam/Nej-till-reklam/.

Latour, B. (2005). Reassembling the social: an introduction to actor-network-theory. Oxford, University Press.

Lindberg, K. and B. Czarniawska (2006). "Knotting the action net, or organizing between organizations." Scandinavian Journal of Management 22(4): 292-306.

Lindberg, K. and L. Walter (2013). "Objects-in-use and organizing in action nets: a case of an infusion pump." Journal of Management Inquiry 22(2): 212-227.

Ljunggren Söderman, M., D. Palm, et al. (2011). Förebygga avfall genom kretsloppsparker [Preventing Waste through Eco-Cycle Parks], IVL Swedish Environmental Research Institute

Naturvårdverket (2012). Från avfallshantering till resurshushållning: Sveriges avfallsplan 2012-2017 [From waste management to resource management: Sweden's waste plan 2012-2017]. Stockholm, Naturvårdsverket.

NSR (2007). Putting the Environment First. Helsingborg, Nordvästra Skånes Renhållnings AB.

NSR. (2011). "Helkund hos NSR." Retrieved August 16, 2011, from http://www.nsr.se/Default.aspx?ID=38.

NSR. (2011). "NSR ${ }^{\circledR}$ Xakt." Retrieved August 16, 2011, from http://www.nsr.se/Default.aspx?ID=193. NSR (2013). Årsredovisning 2012 [Annual Report 2012]. Helsingborg, Nordvästra Skånes Renhållnings $A B$.

Powell, W. W. and P. J. DiMaggio (1991). The new institutionalism in organizational analysis. Chicago, University of Chicago Press. 
Pre Waste (2010). Mapping report on waste prevention practices in territories within EU27. Brussels, European Union.

SFS (1998:808). Miljöbalk [Environemental code]. Stockholm, Svensk författningsamling.

Shove, E. (2010). "Beyond the ABC: climate change policy and theories of social change." Environment and Planning A 42(6): 1273-1285.

Sunfleet. (2013). "Om Sunfleet." Retrieved October 29, 2013, from www.sunfleet.com. Svensk Direktreklam. (n.a.). "Nej tack till reklam." Retrieved October 29, 2013, from http://www.delareklam.nu/index.php?page=om-oss.

TV4. (2013). "Nej till reklam kan leda till körförbud." Retrieved October 29, 2013, from http://wwworigin.tv4play.se/program/nyheterna-\%C3\%B6stersund?video_id=2307445.

UNEP (2011). Decoupling natural resource use and environmental impacts from economic growth, A Report of the Working Group on Decoupling to the International Resource Panel. FischerKowalski, M., Swilling, M., von Weizsäcker, E.U., Ren, Y., Moriguchi, Y., Crane, W., Krausmann, F., Eisenmenger, N., Giljum, S., Hennicke, P., Romero Lankao, P., Siriban Manalang, A. Nairobi, United Nations Environment Programme.

Weick, K. E. (1979). The social psychology of organizing. New York, McGraw-Hill.

Weick, K. E. (1995). Sensemaking in organizations. Thousand Oaks (CA), Sage.

Weick, K. E. (2011). "Reflections: Change Agents As Change Poets - On Reconnecting Flux and Hunches." Journal of Change Management 11(1): 7-20.

Wiesner, M. (2013). EFIC comments on French Regulation 2012-22 (Letter to Commissioner Barnier and Commissioner Tajani, European Commission). Bruxelles, EFIC - European Furniture Industries Confederation.

Zapata Campos, M. J. and M. Hall, Eds. (2013). Organising waste in the city: international perspectives on narratives and practices. Bristol, The Policy Press.

Zapata Campos, M. J. and P. Zapata (2013). Urban waste: closing the system. Resilient Sustainable Cities: A Future. R. Peter, P. Newton and L. Pearson. London, Taylor and Francis / Routledge: 139-145. 